\section{む す}

本稿では主として最近の宇宙開発と関連して発達した 高速飛翔体を対称としたセラミック材料その他複合材料 の特性および用途の概要について紹介したがここ10年間 にわたる高温工学とくに超高温材料の新しい開発と物性 に関する論文がすでに数十冊の多数の国際シンボジウム の刊行物としてまとめられている点からも米ンのみなら

\section{文}

1) Collins: Metal Progress, Jan. (1953)

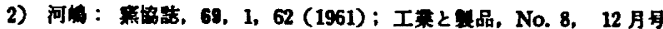

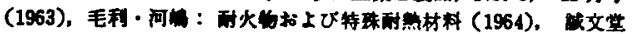

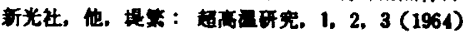

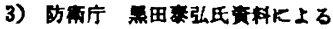

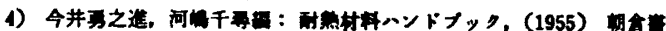

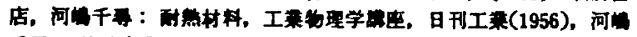

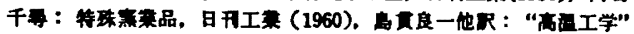
(1963) コロ+住 (I. Campbell \&. High Temp. Technology)

5) ASTM Special Techn. Pub. No.153 (1953), 田代仁：珆㻦工

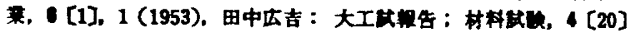
22 (1955)

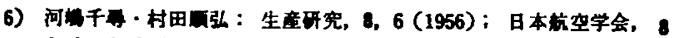
(77). [79] (1960)

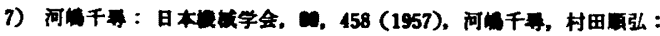

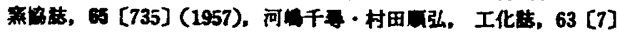

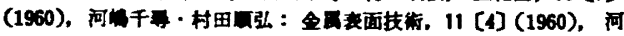

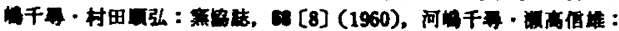

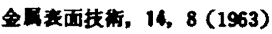

8) W. Lozier \& M. Manofsky : Mech. Properties of Eng. Ceramics (1961). Materials in Design Eng, April 147 (1958)

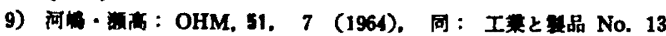

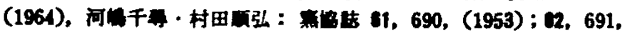
(1954); 12, 694, (1954); 13, 706, (1955); 63, 706, (1955);

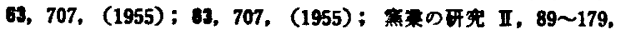
(1961) 察好落, 11, 1, (1961)
ず諸外国での関心の深さをうかがい知ることができる。 このような新しい分野の開発は単に限られた専門分野 のみならず理工学部門を専攻する多くの方々の協力をま たねばならねところがきわ多いが，本稿が宇宙技 街，原子力および電子工業などと関連して飛櫂的進展を 遂げたセラミックスを中心とした新しい無機材料工学へ の認識と今後のわが国での高温工学の発展に対する一つ の手拇りとすなれば誠に幸いである。

堿

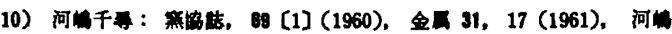

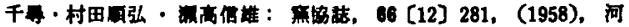

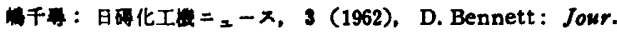
Amer. Ceram. Soc., 30, 10 (1947)

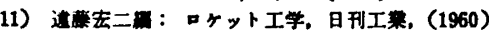

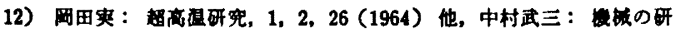
免, 1 [1] 1, 1 (1962); 14 [1] 1 (1962); 14 [2] 273 (1962),

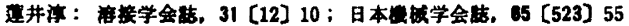
(1962); 棫の研究, 15，5，(1963)

13） D. Moore 他: Nat. Bureau of Std. ARL 59, August (1961)

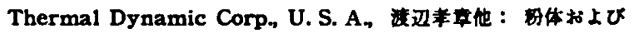
第末治金, 11, 3, 23 (1964)

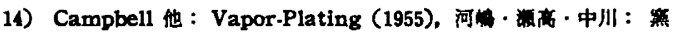

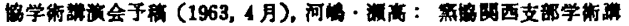
学会予梳 (1964，6月)

J. Pentecost: High Temp. Inorgani, Coating (1963) J. Bloche and J. Oxley : Am. Cerm. Bull. c 41, 2, 81 (1962)

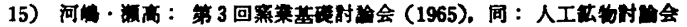
(1965)

16) Proceedings of an International Symposium on High Temp. Techn. Oct. (1959)

F. Wolff : Special Ceramics, 127 (1962)

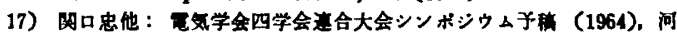

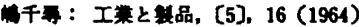

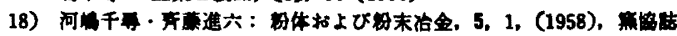
68, 9. (1958), 68, 10 (1958), 化学と工萧, 13, [12] (1960), 工菜と品, No.1, 5月, 1963

\title{
高温における流体の熱物 性*
}

はじめに

高温を利用する各種近代工莱における温度の限界は, 最商条件の存在する化学平衡の場合を除くと，高温を発

*昭和 41 年9月5日 受理

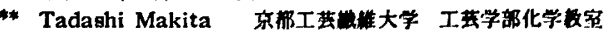

蒔田董**

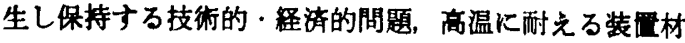
料,ならびに高温における物性に関する知識の欠如によ ることが多い。最近の高温に関する工学的興味は，原子 力の平和利用と，人工衛星で代表される宇宙空間技術に 樂中している感がある。前者については，言5まであな く熱エネルギー変換サイクルでは高温はど熱効串がよ 
く，後者では高速エンジンとその周囲は高温となり，各 種の耐熱材料・伝熱流体・燃赎ガスや察囲気の物性に関 する知裁が要求される。従って，この方面に関する多数 の研究が発表されている。耐熱材料を主とした固体物性 に関しては，全世界の研究を網羅した文献集1) る定期的 に刊行されているので，本稿では比較的稆介されていな い流体について, 高温工学飞必要な基礁的性質の一般的 傾向を概説し，新しいクーラントとして注目されている 融解金属とその蒸気の性質について記述する。ここで熱 物性とは云熱・流動・物質移動などの操作に必要な基碟 物性の総称で，熱力学性質・榆送現象性質および熱放射 性質を含むるのである。また温度箅囲は，信頼できる物 性值の存在する工学的高温の筑囲にとどめ, 超高温にお けるブラズマ状隹などには螌れないこととした。

\section{熱物性研究の最近の功向}

最近の研究の動向を知る上で, アメリカ機械工学会の 层熱部門が主催して 3 年毎に開かれる熱物性シンボジウ ムには，多数の興味ある研究が発表されている。過去 3 回の会合に発表された研究を便宜的に分類して下表に示 す。諭文数こそ少ないか，研究内容は気・液・固の三態

\begin{tabular}{|c|c|c|c|c|}
\hline & & 第 1 回 & 第 2 回 & 第 3 回 \\
\hline 间 & 倍 時 期 & 1959年 2 月 & 1962年 1月 & 1965年 3 月 \\
\hline 間 & 侺 场 & Purdue 大学 & Princeton 大学 & Purdue 大学 \\
\hline 研 & 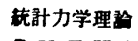 & 2 & 5 & 5 \\
\hline 解 & $P-V-T$ 的係 & 5 & 6 & 10 \\
\hline s & 策力学性萑 & 14 & 18 & 8 \\
\hline 文 & 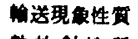 & 17 & 33 & 16 \\
\hline 数 & 敏故射性空 & 2 & 6 & 4 \\
\hline & 数件処理 & 2 & - & - \\
\hline
\end{tabular}

にわたり, 温度・圧力の厇い範囲をカバーしている。過 去の研究に関する総説・維計力学々分子物理に基つく理 論・新しい湘定技術 - 実测值と理論值の阅連 - 程験的推 算法なと，物理・化学・材料化学・化学工学・機械工学 などの仏い分野にわたっている。第 1 回2)には，ホウ素 化合物の熟力学的性質々，解離また恛離した気体の熟 物性に阅す万研究が集められ，第 2 回 $^{3)}$ では, 電離気体. 非ニニートン流体の性貿が特集されている。第 3 回いで は，高温高压における第物性の最す進歩した局面を表わ す論文を集め，理論と実検の関連に努力が厸われ，特に 高温における測定技術や耐熱材料に威与る研究が多い。 しかし，ナへてて研究が温度や圧力の極限にいどむすの ではなく，比校的標算状䈍に近い領城で精度の高い地味 な測定す継繶的に行なわれている。これらの結果の菓 は, 現存する理論の恰討や新しい理論の形成に页献し, やがて央測不可能な高温筑囲での物性值の計算にも役立 つるのである。最近の高速䉓子計算機の進歩に伴ない䙡
雑な理論式の解決も容易となり，個々の物性値を電子計 算機に掛け得る半経耠式の形に整理することも重要な問 題となり，計算結果を直接技術的に利用できる数表の形 で発表されているのも新しい傾向である。

\section{熱物性に対する温度の影雪}

一般に物質の熱物性は，外部变数としての温度と圧力 (または密度)の関数として取り扱われる。したがって, るし分子の内部構造に変化がなければ，一定圧力に甜け る熱物性は温度に関して連続的な誉動を示すはずであ る。しかし，温度の上年に伴い解離あるいはイオン化か 進行し, また分子内のエネルギーの持ち方一回転・振 動あるいは電子状態——変化が起こると，内部構造に 敏感な性質には異常な温度の影警が表わされる。

一般熱物性は，巨視的に系の平衡状態で表われる熱 力学性質と, 系内に何らかの勾配が存在するときに表わ れる棆送現象性質に大別される。また別の分類法として 分子内性質と分子間性質に分けることも便利である。前 者は主として分子の内部構造に基因し，後者では二個以 上の分子間の相互作用が重要である。理想気体の熱力学 性質のことく完全に分子の内部構造を表わす数値より計 算できる性質は前者の代表的な例であり，実在気体の $P-V-T$ 関係や陯送定数は後者の例である。すちろん, ナへての性質は内部粠造に関係し, 構造は分子間力の大 きさと型式に影第するので，この分類は便宜的であり， すへての性貿は両者の要素を持つはずである。たとえ ば，粘度は分子間性質であるか，液体の沸点付近の粘度 には分子の回枟が重大となり，高温における多原子分子

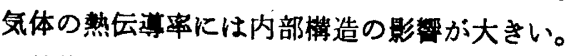

熟物性を温度と圧力の関数として一般性のある相関を 得ることは, 実測値の整理や未知の領域での推算法とし て重要である。分子内性質に咸しては，個々の物質につ いての理論は多いか，多数の分子種に道用できる一般化 を用いるべきであり，球形分子に対する Lennard-Jones 式，非球形分子に対する Kihara 式，極性分子に対する Stockmayer 式が試みられたが，特によい結果は得られ ていない。また式 (1) の左辺の $J_{c}$ の決定が難しく, 同 じ温度における低圧の值や, 䠛界温度における低圧の值 飞置き换える工夫すあり，後述することく次元解析によ ろ方法すある。推算法の詳細に関しては，よくまとめら れた著蓄6、クを参照されたい。

理論や相関の基礎となる実䋡的測定では，高温におけ

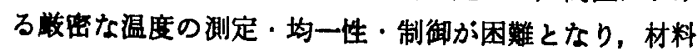
に上る陚料の污染中，高温に括ける材料の物理化学的性 頁の不正磼さのため， $1,000^{\circ} \mathrm{K}$ 以上の湘定例は少なく， 一般に精度も良くない。従って高温で工学的に使用され 
る値は理㻅値か、または経耠的方法により延長された值 である。以下主な熱物性の温度奻果について例を挙げて 一般的傾向を概説する。

$\boldsymbol{P} \boldsymbol{V}-\boldsymbol{T}$ 閶係；最も基本的な熱力学性質で，すべての 物性に対する温度効果の根本的原因となる。滵度・比容 磷・压樎事など実用上の要求る多く，また他の熱力学性 頁の計算にも使用されるため，実測值す比校的鼻富であ り，各種の状態式に関与る研究す多い。特に分子間ボテ ンシャルを用いた梳計力学によるビリフル係数の決定や 係数と他の物性との関速など興味ある問題を含んでい る。対応状態原理に基つく推算法る多く，たとえば，式 の方法は見出されていない。一方，分子間性質に閶して は，分子間ボテンシールk基つく稙々の理論的取りり报

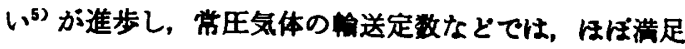
な結果が得られている。また分子間性筫のみに音用でき る「対応状堭の原理」は一般的相阙を得る手段としてか なりの成功をおさめている。元来この原理は「同じ対監 界温度 $T_{r}\left(=T / T_{e}\right) \cdot$ 压力 $P_{r}\left(=P / P_{e}\right)$ Kあるすへての

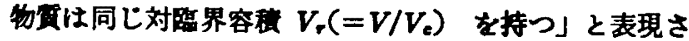

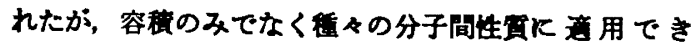
る。たとえば，定圧分子繁と定容分子第の差 $C_{p}-C_{v}$ は $P-V-T$ 関俰から第力学的に算びかれるのでこの原理を 通用できるか，分子内性算である $C_{m} C_{\text {。 }}$ やその比には 通用を試みることは每䭾であり，理想気体との差 $C_{p}-C_{p}{ }^{0}$ には，状態式を用いて不完全気体紏正が行なえるので, この原理が音用できる。いま分子間性貝をJとし，添字 $c$ で界点の俌を示すと，

$$
J / J_{c}=f\left(T_{r}, P_{r}\right)
$$

にてこの原理に基つく相関を表わすことができる。この 関保江非極性球形分子には满足な結果を与えるか，非球 形分子中柾性分子に対しては， $T r, P_{r}$ の泟汃第 3 八 シメーターとして盘界压䗆因子 $z_{e}\left(=P_{e} V_{e} / R T_{e}\right)$ を用い

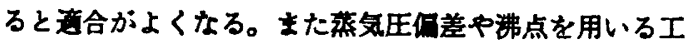

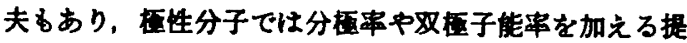
案もある。式 (1) の $T, P$ はそれそれ烸界値を用いて 無次元値に逗元されているが，本貝的には分子間力バラ メーター（1）の $J$ K压綟因子 $z(=P V / R T)$ を用いた チャードや，第3バラメーターを入れた数表”による そ, $T_{r}=15, P_{r}=40$ までの推算が $5 \%$ 以内の俱差で可 能である。しかし，あくまで分子權造に变化のない堵合 に限られる。温度の上䄯に伴い解唯の起こる场合には，

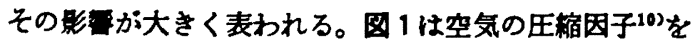
種々の珐力について温度に対してプットしたるのであ ろが, $2,000^{\circ} \mathrm{K}$ 以上の温度では低圧の場合飞解離の影管

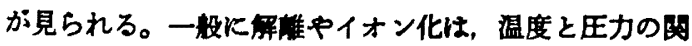
数であるか，多くの二原子分子について，解離は常圧下 2,000 $\mathrm{K}$, イオン化 ${ }^{2 \mathrm{a}}$ は $5,000^{\circ} \mathrm{K}$ 以上で盾大とな
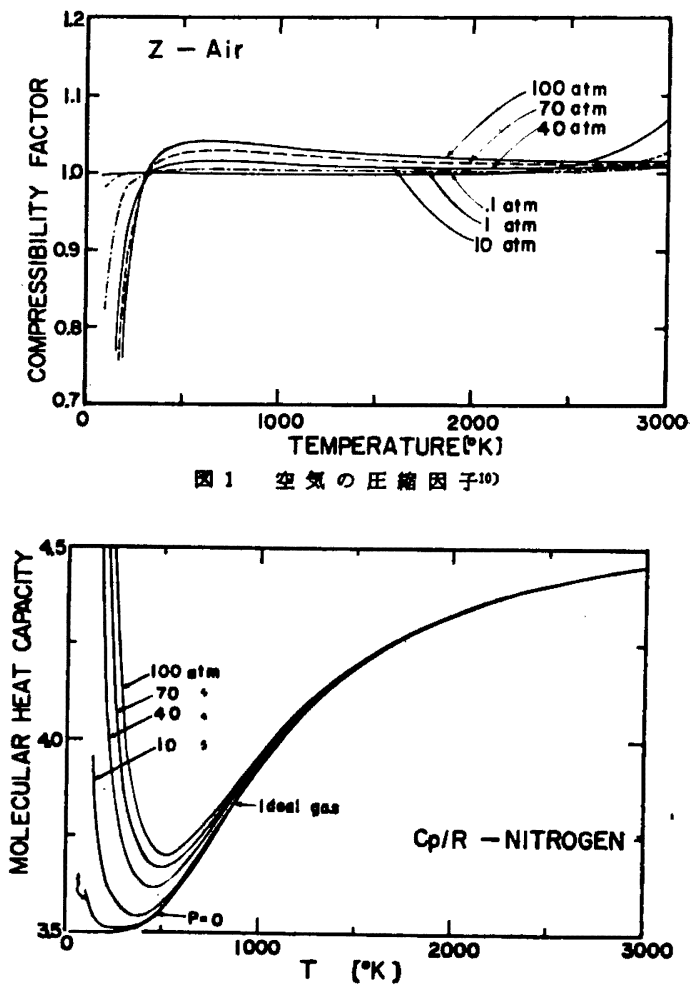

因 $2 \mathrm{~N}_{2}$ の分子来 $C_{p} / R(R \text { は究体定数 })^{10}$

る。

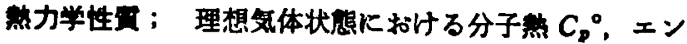
タルピー $H^{0}-H_{0}{ }^{0}$ または $H^{0}-E_{0}{ }^{\circ}\left(H_{0}{ }^{0}, E_{0}{ }^{0}\right.$. 值), エントロピー $S^{0}$, 自由エネルギー $F^{0}-H_{0}^{\circ}$ または $F^{0}-E_{0}{ }^{\circ}$ などは敞密に分子内性筫であり，分子權造デー タを用いて珫計力学により計算される゙11。1950年前後に ほとんどすくての交体につき，新しい物理定数・分光学 的数值・同位元亲組成を用いて再計算され，詳細な数 表10-10) として器表されている。実在気体の值を求的る には，状態式を用いて不完全気体補正が行なわれる。因 2 は隹↔の圧力における $\mathrm{N}_{2}$ の分子繁 ${ }^{10)}$ の温度による変 化を示したるので，温度の上年に伴い圧力効果は少なく なり，高温では理想気体の值に接近する。この四では解

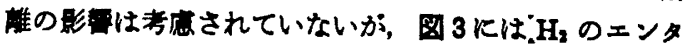
ルビー10)、に対する解唯の影を示した。四中の点線で 示された $P V / R T$ の值により，圧力と温度による解耀の 模侎がよく示されている。

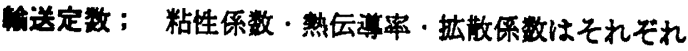

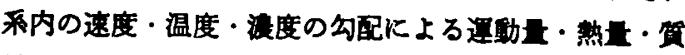

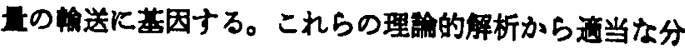
子归ポテンシャルを仮定すると，低圧の棸体の值が計算

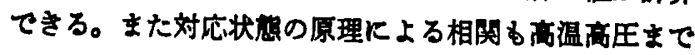




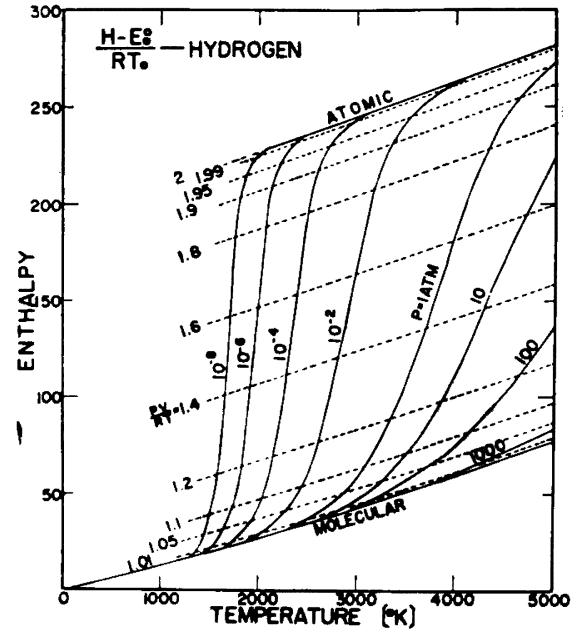

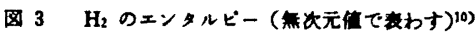

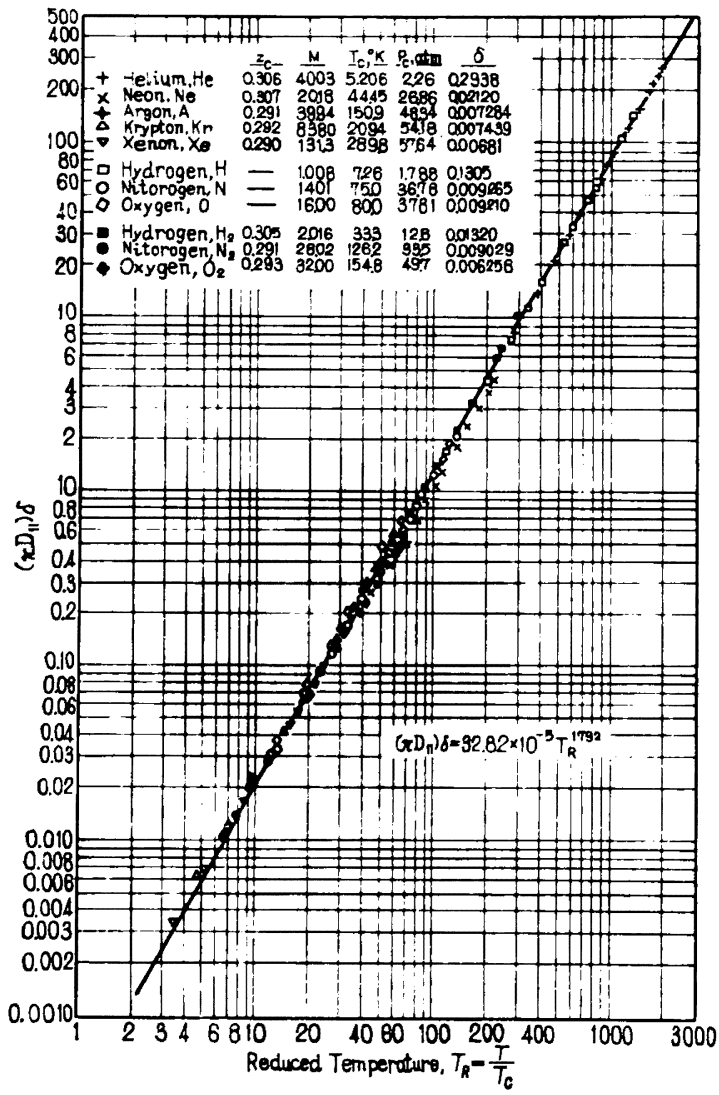

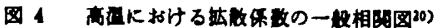

多数の試みがある゙日,15)。粘度の実测值は $1,800^{\circ} \mathrm{C}$ まで 得られている16)が, 高温では理論または経検的な方法に より算出される。最近数程の気体の分子間ボテンシャル が分子線を用いて $1,000 \sim 10,000^{\circ} \mathrm{K}$ にて決定され ${ }^{17}$ ，衝
突稘分の值 ${ }^{18)}$ す得られているので，Mathur $5^{19,20)}$ は その結果を用い，非解離および解離分子に適用できる一 般関係を対応状態の原理に基つき求めている。喻送定数 の無次元化には次元解析の結果次の量を得た。

$$
\begin{array}{ll}
\text { 粘性保数: } \eta_{\xi}=\eta \cdot T_{c}{ }^{1 / 6} / M^{1 / 2} P_{c}{ }^{2 / 3} \\
\text { 熱伝复率: } k_{t} \lambda=k_{t} \cdot T_{c}{ }^{1 / 6} M^{1 / 2} / P_{c}{ }^{2 / 3}
\end{array}
$$$$
\text { 拡散俰数： } \pi D \delta=\pi D \cdot M^{1 / 2} / P_{c}{ }^{2 / 3} T_{c}^{5 / 6}
$$

式中の $M$ は分子量， $k_{t}$ は熱伝導率の併進運動に上る部 分である。これらの值を $T$ r に対してプロットすると各 定数とも単一な曲線を得る。この関俰は単原子および二 原子分子気体とともに，原子状 $\mathrm{H}, \mathrm{N}, \mathrm{O}$ Kついてす成り 立ち，解離平衡系に対しても適用できる。图4 亿は拡散 係数の一般相関図 ${ }^{20)}$ を引用した。これは自己拡散保数 とともに，解離平衡にある分子状と原子状の気体の相互 拡散係数の推算使用できる。なお，式（3）を用いた 熱卮導率の相関の場合には，分子の併進運動による部分 のみに䔔用でき，内部自由度による部分や解倠エネルギ 一の影霨については別に経験式が与えられている。

\section{的解金属とその菜気の性㚇}

従来より熱機関の作動体や冷却媒体として水が広く用 いられてきたが，原子力工学や宇宙空間技術に㸝りる高 温での云衤流体として，化学的に安定な融解金属が重要 である。現在知られている約80種の金属の5ち，伝熱廿 イクルに使用できるものは，融点が比較的低く，しかす 臨界温度までの液体筑囲の広い金属に限られる。通常, 融点が $340^{\circ} \mathrm{C}$ 以下で，常圧下の液体領域が沸点の絶対 温度の $60 \%$ 以上にわたることが望ましく，凝固が起こ ったり，高い繁気圧を生ずるすのは操作上不便である。 同時に，長時間の運枟中に，熱勾配や流動の存在する状 態で装置材料の腐食が起こらないことす重要である。こ れらの点から，伝熱流体として適当な金属を，その使用

\begin{tabular}{|c|c|c|}
\hline 使用组度符田 & 云筩流体 & 芸材料 \\
\hline $\begin{array}{l}320^{\circ} \mathrm{C} \text { 以下 } \\
320 \sim 650^{\circ} \mathrm{C}\end{array}$ & $\begin{array}{c}\mathrm{Hg}_{\mathbf{g}} \\
\mathrm{Hg}, \mathrm{Cg}, \mathrm{Rb}, \mathrm{K}, \mathrm{Na}\end{array}$ & 教 政 \\
\hline $650 \sim 980^{\circ} \mathrm{C}$ & $\mathrm{C}, \mathrm{Rb}, \mathrm{K}, \mathrm{Na}, \mathrm{Li}$ & $\begin{array}{l}\mathrm{Fe}, \mathrm{Co}, \mathrm{Ni} \text {, } \\
\text { 特辣合金 }\end{array}$ \\
\hline $980 \sim 1320^{\circ} \mathrm{C}$ & $\begin{array}{l}\text { Cs, } \\
\mathrm{Bi}_{\mathrm{i}} \mathrm{Pb}\end{array}$ & $\begin{array}{l}\text { Mo, Nb, Ta, w の酷第 } \\
\text { 金合金 }\end{array}$ \\
\hline $1320^{\circ} \mathrm{C}$ 以上 & $\mathrm{Li}, \mathrm{Bi}, \mathrm{Pb}$ & 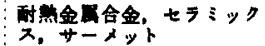 \\
\hline
\end{tabular}
温度箅用と暗当な装固材料ととすに下春に示した。表中

の材料は一般的に举げたすので，耐食性は個々の金属に よりかなり異なるので注意を要する。これらの金属のう ち，密度が小で熱云導率と比熱の大きいアルカリ金属は 効事の高い伝繁流体として注目されている。しかす粘度 は通常の液体汇近く，循環の動力は少なくて済み，循環 


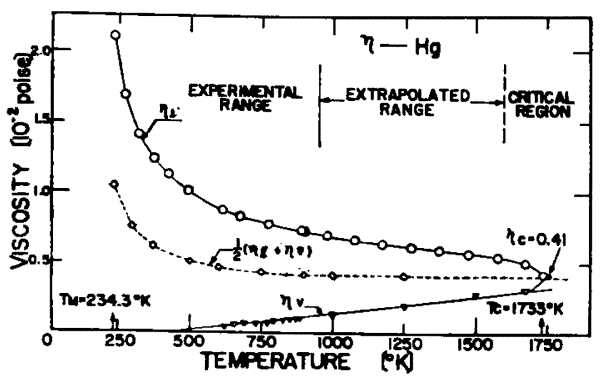

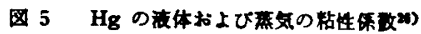
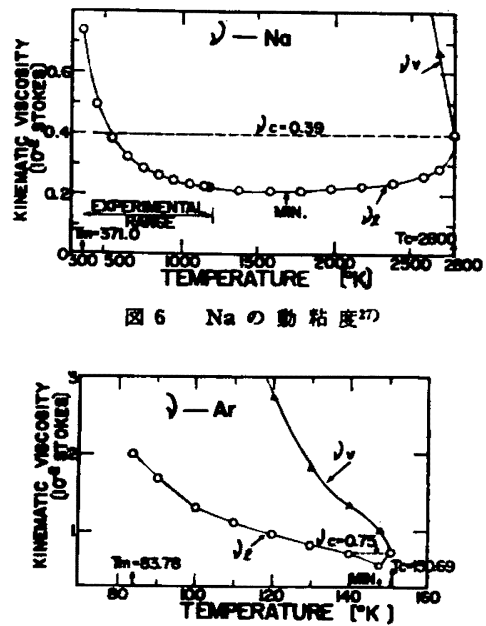

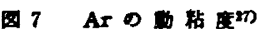

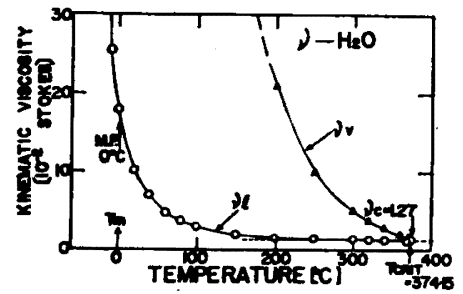

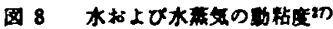

中の玨力降下る少ない。しかし，反庍性に畐むため危険 防止に忙充分考虑する必要がある。

融解金属とその蒸気の熟物性に関しては，実呀・理論 ならびに経検的方法による結果か，工学的目的のため整 理されている21)が，最近の研究はデータ一不足の領域 を補 5方向ととるに，より正確な実测值の決定や推算法 の確立に努力が集中されている。低面の都合上系統的な 解説ができないので，樶近の数報を引用して研究の動向 を知る便に供したい。

蛍解金属の密度や蒸気圧は装膡の設計に重要である。 Hochman 5 ${ }^{\text {(2) }}$ はCs の液体と蒸気の密度を320 1,650
${ }^{\circ} \mathrm{C}$ にて測定し，Mathias-Cailletet の規圧密度の法則を 用いて臨界値 $\left(T_{c}=2,028^{\circ} \mathrm{K}, P_{c}=130.8\right.$ 気圧, $d_{c}=$ $0.451 \mathrm{~g} / \mathrm{cc}$ ) を决定した。Bowles ら ${ }^{22)}$ は融解 $\mathrm{Na}$ の蒸 気圧を $1,000 \sim 2,200^{\circ} \mathrm{K}, 0.5 \sim 120$ 気圧の範囲で静的に 測定し，通常の液体のことくClapeyron-Clausius 型の 程験式を与えている。Kim 5 ${ }^{23)}$ は Pb と Si の蒸気圧を $850 \sim 970^{\circ} \mathrm{K}$ で測定し， $\mathrm{Pb}$ の蒸気は単原子分子である が，Bi ではその 65\%が $\mathrm{Bi}_{2}$ になっていることを指摘し た。温度の上年に伴い解離が進さが，蒸気の熱物性に通 常の気体の理論式を適用するとき，その分子量中会合． 解離に伴 ラエネルギーを考虑する必要がある。

一般に液体金属の陯送定数は金属結合のため複雑とな り，粘度はすへでの金属につき温度により減少するが， 熱伝学度の温度係数は $\mathrm{Na}, \mathrm{K}, \mathrm{Rb}, \mathrm{Cs}$ では負, $\mathrm{Li}, \mathrm{Hg}$, $\mathrm{Pb}, \mathrm{Bi}$ では正であり，その理論的説明はない。Hochman ら治高温で精度の高い電気抵抗の测定から，Wiedemann-Franz-Lorenz の法則を用いて $320 \sim 1650^{\circ} \mathrm{C}$ の Cs の熱伝萝率を算出し ${ }^{26) ， ま た ~} 320 \sim 540^{\circ} \mathrm{C}$ における $\mathrm{K}-\mathrm{Hg}$ 系の拡散係数を定めた ${ }^{(b)}$ 。Grosse は $\mathrm{Na}, \mathrm{K}^{25)} お$ よび $\mathrm{Hg}^{26)}$ Kつき，実測值を用いて Andrade 式の倸数 を定め，融点から臨界点までの飽和夜体の粘度を推算し た。図 5 K Hg の結果を示すか，蒸気の值すブロットし て規圧密度の法則と類似の方法で臨界粘度 $\eta_{c}$ を定めた。

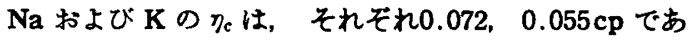
る。これらの結果は動粘度 $\nu$ の計算 ${ }^{27)}$ に使用され，図 6 K Na の例を示すことく，液体の動粘度 $\nu_{l}$ 火は梗小 値であり，液体筑囲の $\nu_{l}$ の值の大部分は $\nu_{c} よ り$ 低い。 非金属液体の代表的な例を图 7，図8 亿示すが，これら より金属液体の特巽性がよく見られる。一方，蒸気の ン。成しては特別の差異は認められず，蒸気になれば 金蚛の特性を失ない通常の気体と類似した举動をするる のと考えられる。

以上の数報からす明らかなことく，しばしば古典的経 呀律が用いられていることは，液体金属に関する理諭の 困難さによるるので，新しい理論の出現が待たれ，同時 に精度の高い実測值が望まれている。

\section{おわりに}

高温における流体のる5一つの重要な熱物性は熱放射 性質であり，また水蒸気・触解塭類や電離気体の性質す 今後の高温工学の発展に重要なるのであるが，紙面の都 合上割舜した。 


\section{引用 文 献}

1) Diamond, J. J. (Ed.): "Bibliography on the High Temperature Chemistry and Physics of Materials in the Condensed State", Commission on High Temperatures and Refractories, International Union of Pure and Applied Chemistry (是布希望者は National Bureau of Standards,

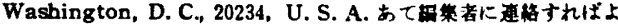
i)

2) Touloukian, Y. S. (Ed.): "Thermodynamic and Transport Properties of Gases, Liquids and Solids", ASME-Mc Graw-Hill Book Co., Inc., New York (1959)

2a) Martinek, F.: Ibid, p. 130

3) Masi, J. F. and D. H. Tsai (Ed.): "Progress in International Research on Thermodynamic and Transport Properties", ASME-Academic Press, New York (1962)

3a) Stiel, L. I. and G. Thodos: Ibid, p. 352

1) Gratch, S. (Ed.): "Advances in Thermophysical Properties at Extreme Temperatures and Pressures", The American Society of Mechanical Engineers, New York (1965)

4a) Hochman, J. M. and C. F. Bonilla: Ibid, p. 122

4b) Bonilla, C. F., D. I. Lee and P. J. Foley: Ibid. p. 207

5) Hirschfelder, J. O, C. F. Curtiss and R. B. Bird: "Molecular Theory of Gases and Liquids", John Wiley \& Sons, New York (1954)

6) Reid, R. C. and T. K. Sherwood: "Properties of Gases and Liquids". McGraw.Hill, New York (1958) 近く改影版 が田る于定てちる。

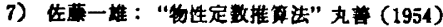

8) Nelson, L. C. and E. F. Obert: Mech. Eng., 76, 280 (1954); Obert, E. F.: "Concepts of Thermodynamics". Mc GrawHill Book Co., New York (1960)

9) Lydersen, A. L., R. A. Greenkorn and O. A. Hougen: Univ. of Wisc. Eng. Expt. Sta. Report 4, (1955); Cominge, E. W.: "High Pressure Technology", McGraw.Hill Book Co, New York (1956)

10) Hileenrath, J., C. W. Beckett, W. S. Benedict, L. Fano, H. J. Hodge, J. F. Masi, R. L. Nuttall, Y. S. Touloukian and H. W. Wooley: "Tables of Thermal Properties of Gases", National Bureau of Standards Circ. 564 (1955)

11) Mayer, J. E., M. G. Mayer: "Statistical Mechanics", John Wiley \& Sons, New York (1940)
12) Rossini, F. D., K. S. Pitzer, R. L. Arnett, R. M. Braun and G. C. Pimental: "Selected Values of Physical and Thermodynamic Properties of Hydrocarbons: and Related Compounds", Carnegie Press, Pittsburgh, Pa. (1953); American Petroleum Institute Research Project $44, \mathrm{Ch}$. em. Thermo. Properties Center, College of Texas, College Station, Texas (1953)

13) Stull, D. R., et al. : "JANAF Thermochemical Tables", Thermal Research Lab., The Dow Chem. Co., Midland, Mich. (1960-2)

14) McBride, B. J, S. Heimel, J. G. Ehlers and S. Gordon: "Thermodynamic Properties to $6000^{\circ} \mathrm{K}$ for 210 Substances Involving the First 13 “Elements", NASA SP-3001, National Aeronautics and Space Administration, Washingt-on, D. C. (1963)

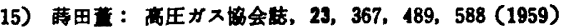

16) Bonilla, C. F., S. J. Wang and H. Weiner: Trans. ASME. 78. 1285 (1956)

17) Amdur, I., et al.: J. Chem. Phys., 22, 664, 670 (1954); 23 . 415. 2268 (1955) ; 25, 624 (1956) ; 27, 527 (1957)

18) Amdur, I. and E. A. Mason: Phys. Fluids, 1, 370 (1958) Vandersl ice, J. T., S. Weissman, F. A. Mason and R. J. Fallon: Ibid., 5, 155 (1962) Yun, Kwang-sik, S. Weisgman and E. A. Mason: Ibid, 672 (1962)

19) Mathur, G. P. and G. Thodos: A. I. Ch. E. J, 8, 596 (1963),

20) Mathur, G. P. and G. Thodos: A. I. Ch. E. J., 11, 164 (1965)

21) Weatherford, W. D. Jr., J. C. Tyler and P. M. Ku: "Properties of Inorganic Energy-Conversion and Heat-Transfer Fluids for Space Applications". WADD Tech. Rept, 61-96 (1961)

22) Bowles, K. J. and L. Rosenblum: J. Chem. Eng. Data, 10, 321 (1965)

23) Kim, J. H. and A. Coegarea, Jr.: J. Chem. Phys, 44, 806: (1966)

24) Hochmann, J. M. and C. F. Bonilla: Nucl. Sci. Eng, 22, 434 (1965)

25) Gronse, A. V.: Science, 147, 1438 (1965)

26) Groses, A. V.: J. Phys. Chem., 80, 3419 (1964)

27) Grosee, A. V.: J. Inorg. Nucl. Chem, 28, 31 (1966)

[特集科わり 